Syntax Literate : Jurnal Ilmiah Indonesia p-ISSN: 2541-0849

e-ISSN : 2548-1398

Vol. 6, No. 1, Januari 2021

\title{
PERAN KINERJA KEUANGAN DALAM MEMEDIASI ISLAMIC CORPORATE GOVERNANCE TERHADAP FRAUD
}

\section{Siti Juariah, Dinnul Alfian Akbar dan Titin Hartini}

Universitas Islam Negeri Raden Fatah Palembang, Sumatera Selatan, Indonesia

Email: tyasjuju21@gmail.com, dinnulalfianakbar_uin@radenfatah.ac.id dan titinhartini_uin@radenfatah.ac.id

\section{Abstract}

Fraud can be defined as a deviation or illegal act which is done intentionally, for a specific purpose. Fraud in the view of Islam is disgraceful act, because it is already detrimental to others. If humans commit fraud then that person is not respect honesty in achieving a goal. This study aims to analyze the influence of independent variables which is Shariah Compliance on Fraud while Financial Performance as a mediator variable. This study uses secondary data derived from the Annual Report and Good Corporate Governance Report 2015 to 2019 of Islamic Banking that registered in Bank Indonesia. This study use Structural Equation Modeling (SEM) software, especially Partial Least Square (PLS). The result of this study are: Islamic Corporate Governance has a negative effect on Fraud; Islamic Corporate Governance has a positive significant effect on Financial Performance; Financial Performance has a negative significant effect on Fraud; and Financial Performance Full Mediate Islamic Corporate Governance on Fraud.

Keywords: islamic corporate governance; fraud; financial performance

\begin{abstract}
Abstrak
Fraud dapat didefinisikan sebagai penyimpangan atau perbuatan melanggar hukum (Illegal Acts) yang dilakukan dengan sengaja, untuk tujuan tertentu Penipuan dalam pandangan Islam adalah perbuatan tercela, karena sudah merugikan orang lain. Jika manusia melakukan penipuan maka orang tersebut tidak menghargai kejujuran dalam mencapai suatu tujuan. Penelitian ini bertujuan untuk menganalisis pengaruh variabel independen yaitu Shariah Compliance terhadap Fraud sedangkan Kinerja Keuangan sebagai variabel mediator. Penelitian ini menggunakan data sekunder yang berasal dari Laporan Tahunan dan Laporan Good Corporate Governance 2015-2019 Perbankan Syariah yang terdaftar di Bank Indonesia. Penelitian ini menggunakan software Structural Equation Modeling (SEM), khususnya Partial Least Square (PLS). Hasil penelitian ini adalah: Islamic Corporate Governance berpengaruh negatif terhadap Fraud; Islamic Corporate Governance berpengaruh signifikan positif terhadap Kinerja Keuangan; Kinerja Keuangan berpengaruh signifikan negatif terhadap Fraud; dan Kinerja Keuangan Memediasi pengaruh Islamic Corporate Governance terhadap Fraud.
\end{abstract}

Kata kunci: tata kelola perusahaan islam; fraud; kinerja keuangan 
Coresponden Author

Email: tyasjuju21@gmail.com Artikel dengan akses terbuka dibawah lisensi

\section{Pendahuluan}

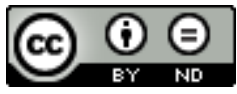

Pada teorinya perbankan syariah harus memenuhi prinsip Islam/syariah. Konsep dasar akuntansi yang dipilih akan menentukan perlakuan terhadap transaksi-transaksi tersebut. Sebagaimana dalam Peraturan Bank Indonesia No. 10/16/PBI/2008 pada pasal 2 ayat 3 dijelaskan bahwa pemenuhan prinsip Syariah harus dilaksanakan dengan memenuhi ketentuan pokok hukum Islam antara lain prinsip keadilan dan keseimbangan (adl wa tawazun), kemaslahatan (maslahah) dan universalisme (alamiyah) serta tidak mengandung gharar, maysir, riba, zalim dan objek haram. Salah satunya nilai terpenting dalam prinsip syariah yang juga menjadi tujuan dari prinsip syariah (Maqashid Syari'ah) yaitu, nilai maslahah.

Selama ini evaluasi Bank Syariah cenderung memprioritaskan aspek-aspek keuangan saja yang seharusnya Bank Syariah juga tidak melupakan aspek-aspek Islam yang perlu diterapkan pada Bank Syariah. Apakah adanya unsur syariah menjamin suatu lembaga terbebas dari tindak kecurangan? Kenyataannya tidak, terbukti dengan adanya kasus-kasus fraud yang terjadi di Perbankan Syariah (Fadhistri \& Triyanto, 2019).

Fraud dapat didefinisikan sebagai penyimpangan atau perbuatan melanggar hukum (Illegal Acts) yang dilakukan dengan sengaja, untuk tujuan tertentu, misalnya menipu atau memberikan gambaran yang keliru (mislead) untuk keuntungan pribadi atau kelompok secara tidak fair baik secara langsung maupun tidak (Rajagukguk, 2017). Di Indonesia telah banyak terjadi kasus-kasus fraud di lembaga syariah. Seperti kasus yang terjadi pada Bank Syariah Mandiri cabang Bogor terkait penyaluran fiktif yang melibatkan pihak internal bank yaitu sebesar 102 miliar rupiah kepada 197 nasabah fiktif yang disebabkan oleh manajemen yang buruk serta sistem akuntansi dan manajemen yang tidak tepat (Rini, 2014). Kasus tersebut membuktikan bahwa lembaga syariah dan bank yang berbasis syariah tidak menjamin bebas dari tindakan fraud. Pada dasarnya terdapat dua sumber kecurangan, yaitu ekstemal dan internal. Kecurangan eksternal (external fraud) adalah kecurangan yang dilakukan oleh pihak luar terhadap entitas. Misalnya, kecurangan ekstemal mencakup: kecurangan yang dilakukan pelanggan terhadap usaha; wajib pajak terhadap pemerintah; atau pemegang polis terhadap perusahaan asuransi. Oleh pihak di luar perusahaan, yaitu pelanggan, mitra usaha, dan pihak asing yang dapat menimbulkan kerugian bagi perusahaan. Tipe kecurangan yang lain adalah kecurangan internal (internal fraud). Kecurangan internal adalah tindakan tidak legal dari karyawan, manajer dan eksekutif terhadap perusahaan.

Bank syariah sebagai entitas dengan identitas berbasis agama, diharapkan mampu menjalankan nilai-nilai etika Islam dengan kegiatan mereka. Islam mendorong terlaksananya ICG yang baik pada perusahaan dengan tujuan untuk kepentingan stakeholder. Konsep corporate governance (CG) dalam Islam sangat menekan pentingnya transparansi dan kepercayaan (Erasiska, Bali, \& Hanifah, 2015). Bank 
syariah yang memiliki indexs CG dalam kategori tinggi secara siginifikan beroperasi lebih efisien dan mampu memperoleh laba tertinggi dan sebaliknya bank syariah dengan indeks CG rendah secara signifikan kinerja keuangannya juga rendah (Safieddine, 2009). Berdasarkan semangat transparansi dan akuntabilitas, bank syariah diharapkan mampu mengungkapkan fitur ICG dengan baik kepada stakeholder mereka, sehingga memungkinkan stakeholder untuk menilai bagaimana pengelolaan bank serta bagaimana investasi dikelola sesuai dengan prinsip kehati-hatian.

Menurut (Endraswati, 2015) corporate governance dalam Islam adalah sistem yang mengarahkan dan mengendalikan perusahaan untuk memenuhi tujuan perusahaan dengan melindungi kepentingan dan hak semua stakeholder dengan menggunakan konsep dasar pengambilan keputusan berdasarkan epistemologi sosial-ilmiah Islam yang didasarkan pada ketauhidan Allah. Tujuan utama islamic corporate governance adalah maqasid shariah yang merujuk pada kesejahteraan masyarakat. Kemurnian prinsip syariah harus ditingkatkan agar bank syariah dapat beroperasi sesuai prinsip itu serta sekaligus dapat meminimalkan risiko citranya sebagai lembaga beratribut syari' ah.

Selama ini evaluasi Bank Syariah cenderung memprioritaskan aspek-aspek keuangan saja yang seharusnya Bank Syariah juga tidak melupakan aspek-aspek Islam yang perlu diterapkan pada Bank Syariah. Apakah adanya unsur syariah menjamin suatu lembaga terbebas dari tindak kecurangan? Kenyataannya tidak, terbukti dengan adanya kasus-kasus fraud yang terjadi di Perbankan Syariah (Fadhistri \& Triyanto, 2019).

Fraud dapat didefinisikan sebagai penyimpangan atau perbuatan melanggar hukum (Illegal Acts) yang dilakukan dengan sengaja, untuk tujuan tertentu, misalnya menipu atau memberikan gambaran yang keliru (mislead) untuk keuntungan pribadi atau kelompok secara tidak fair baik secara langsung maupun tidak (Rajagukguk, 2017). Di Indonesia telah banyak terjadi kasus-kasus fraud di lembaga syariah. Seperti kasus yang terjadi pada Bank Syariah Mandiri cabang Bogor terkait penyaluran fiktif yang melibatkan pihak internal bank yaitu sebesar 102 miliar rupiah kepada 197 nasabah fiktif yang disebabkan oleh manajemen yang buruk serta sistem akuntansi dan manajemen yang tidak tepat (Rini, 2014). Kasus tersebut membuktikan bahwa lembaga syariah dan bank yang berbasis syariah tidak menjamin bebas dari tindakan fraud. Pada dasarnya terdapat dua sumber kecurangan, yaitu ekstemal dan internal. Kecurangan eksternal (external fraud) adalah kecurangan yang dilakukan oleh pihak luar terhadap entitas. Misalnya, kecurangan ekstemal mencakup: kecurangan yang dilakukan pelanggan terhadap usaha; wajib pajak terhadap pemerintah; atau pemegang polis terhadap perusahaan asuransi. Oleh pihak di luar perusahaan, yaitu pelanggan, mitra usaha, dan pihak asing yang dapat menimbulkan kerugian bagi perusahaan. Tipe kecurangan yang lain adalah kecurangan internal (internal fraud). Kecurangan internal adalah tindakan tidak legal dari karyawan, manajer dan eksekutif terhadap perusahaan.

Bank syariah sebagai entitas dengan identitas berbasis agama, diharapkan mampu menjalankan nilai-nilai etika Islam dengan kegiatan mereka. Islam mendorong terlaksananya ICG yang baik pada perusahaan dengan tujuan untuk kepentingan stakeholder. Konsep corporate governance (CG) dalam Islam sangat menekan 
pentingnya transparansi dan kepercayaan (Erasiska et al., 2015). Bank syariah yang memiliki indexs CG dalam kategori tinggi secara siginifikan beroperasi lebih efisien dan mampu memperoleh laba tertinggi dan sebaliknya bank syariah dengan indeks CG rendah secara signifikan kinerja keuangannya juga rendah (Safieddine, 2009). Berdasarkan semangat transparansi dan akuntabilitas, bank syariah diharapkan mampu mengungkapkan fitur ICG dengan baik kepada stakeholder mereka, sehingga memungkinkan stakeholder untuk menilai bagaimana pengelolaan bank serta bagaimana investasi dikelola sesuai dengan prinsip kehati-hatian.

Menurut (Endraswati, 2015) corporate governance dalam Islam adalah sistem yang mengarahkan dan mengendalikan perusahaan untuk memenuhi tujuan perusahaan dengan melindungi kepentingan dan hak semua stakeholder dengan menggunakan konsep dasar pengambilan keputusan berdasarkan epistemologi sosial-ilmiah Islam yang didasarkan pada ketauhidan Allah. Tujuan utama islamic corporate governance adalah maqasid shariah yang merujuk pada kesejahteraan masyarakat. Kemurnian prinsip syariah harus ditingkatkan agar bank syariah dapat beroperasi sesuai prinsip itu serta sekaligus dapat meminimalkan risiko citranya sebagai lembaga beratribut syari'ah.

\section{A. Signalling Theory}

Menurut (Eugene \& Houston, 2010) isyarat atau signal adalah suatu tindakan yang diambil perusahaan untuk memberi petunjuk bagi investor tentang bagaimana manajemen memandang prospek perusahaan. Sinyal ini berupa informasi mengenai apa yang sudah dilakukan oleh manajemen untuk merealisasikan keinginan pemilik. Informasi yang dikeluarkan oleh perusahaan merupakan hal yang penting, karena pengaruhnya terhadap keputusan investasi pihak diluar perusahaan. Informasi tersebut penting bagi investor dan pelaku bisnis karena informasi pada hakekatnya menyajikan keterangan, catatan atau gambaran, baik untuk keadaan masa lalu, saat ini maupun masa yang akan datang bagi kelangsungan hidup perusahaan dan bagaimana efeknya pada perusahaan.

Signalling theory menjelaskan mengapa perusahaan mempuyai dorongan untuk memberikan informasi laporan keuangan pada pihak eksternal. Dorongan perusahaan untuk memberikan informasi karena terdapat asimetri informasi antara perusahaan dan pihak luar karena perusahaan mengetahui lebih banyak mengenai perusahaan dan prospek yang akan datang daripada pihak luar (investor dan kreditor). Kurangya informasi bagi pihak luar mengenai perusahaan meyebabkan mereka melindungi diri mereka dengan mmberikan harga yang rendah untuk perusahaan. Perusahaan dapat meningkatkan nilai perusahaan dengan mengurangi informasi asimetri. Salah satu cara untuk mengurangi informasi asimetri adalah dengan memberikan sinyal pada pihak luar (Arifin, 2005). Jadi keterkaitan teori sinyal dengan variable penelitian berdasarkan uraian diatas ialah sinyal yang diberikan oleh perusahaan dalam laporan keuangan akan memberikan sinyal kepada pihak internal untuk melakukan tindak kecurangan. 


\section{B. Teori Agensi}

Teori agensi merupakan hal dasar yang digunakan untuk memahami hubungan antara principle dan agent. Dalam hal ini hubungan keagenan merupakan kontrak antara satu orang atau lebih yang mempekerjakan orang lain untuk memberikan suatu jasa dan kemudian mendelegasikan wewenang pengambilan keputusan kepada agen tersebut (Jensen \& Meckling, 1976). Berdasarkan teori ini, terjadi pemisahan antara pemilik (principal) dan pengelola perusahaan (agent) sehingga menimbulkan agency problem. Selanjutnya pemisahan pemilik dan pengelola juga menimbulkan asimetri informasi yaitu suatu keadaan dimana agent memiliki akses informasi yang tidak dimiliki oleh pihak principle. Asimetri informasi muncul ketika agent lebih banyak mengenal (mengetahui) informasi internal dan prospek masa yang akan datang, dibandingkan pengetahuan tentang informasi yang diketahui oleh principal dan stakeholder lainnya (Anugrah, 2018). Berdasarkan asumsi sifat dasar manusia, setiap manusia memiliki kecenderungan untuk bertindak dengan mengutamakan kepentingan pribadinya. Perbedaan kepentingan menyebabkan agen menyalahgunakan kewajibannya dalam penyampaian informasi kepada prinsipal dengan cara memberikan atau menahan informasi yang diminta prinsipal bila menguntungkan bagi agen. Untuk mengatasi hal tersebut, diperlukan penerapan Good Corporate Governance beserta prinsip-prinsip dan mekanismenya untuk dapat memastikan hak dan hubungan di antara seluruh stakeholder ini terjamin. Jadi, hubungan antara teori agensi ini dengan fraud pada bank syariah ialah pada akibat yang mungkin timbul dari adanya agency problem yaitu asimetri informasi, dimana informasi yang dimiliki oleh agen digunakannya untuk mengambil keuntungan bagi dirinya sendiri atau orang lain yang dapat mengakibatkan kerugian bagi prinsipal maupun perusahaan. Meskipun bank syariah menggunakan prinsip-prinsip Islam, hal tersebut tidak menjamin bank syariah terbebas dari adanya tindakan fraud karena fraud bisa saja terjadi dan berasal dari lingkungan internal bank syariah sendiri. Oleh karena itu pentingnya penerapan Islamic Corporate Governance pada Bank Syariah.

Penelitian yang berkaitan dengan Islamic Corporate Governance terhadap fraud antara lain penelitian yang dilakukan (Fadhistri \& Triyanto, 2019) dengan hasil penelitian yakni Islamic Corporate Governance berpengaruh terhadap fraud pada Bank Umum Syariah berbeda dengan penelitian (Najib \& Rini, 2016), menyatakan bahwa Islamic Corporate Governance tidak berpengaruh terhadap fraud pada bank syariah. (Rahmayani \& Rahmawaty, 2017), (nur'aini, 2016), menyatakan bahwa Islamic Corporate Governance diproksikan dengan DD, DKI, DK DPS dan KA tidak memiliki pengaruh signifikan terhadap terjadinya fraud. Menurut (Ngumar, Fidiana, \& Retnani, 2019) Islamic Corporate Governance yang diproksikan dengan DD, DKI, DK DPS dan KA memiliki pengaruh negatif terhadap fraud pada bank syariah.

Penelitian yang berkaitan dengan Islamic Corporate Governance terhadap Kinerja keuangan antara lain ialah penelitian yang dilakukan Jaya Laksana (2012) 
mengungkapkan bahwa Islamic Corporate Governance dengan variable dewan direksi berpengaruh positif signifikan terhadap kinerja keuangan pada bank di Indonesia. Hal tersebut tidak senada dengan penelitian yang dilakukan oleh (Novitasari, Diana, \& Mawardi, 2017) yang mengungkapkan bahwa Islamic Corporate Governance dengan indicator dewan pengawas syariah negatif signifikan terhadap kinerja keuangan. Sedangkan penelitian (Handayani, 2013) mengungkapkan bahwa Islamic Corporate Governance dengan variable dewan komisaris tidak berpengaruh terhadap kinerja keuangan.

Sedangkan penelitian tentang kinerja keuangan terhadap fraud telah dilakukan oleh (Eugene \& Houston, 2010) kinerja keuangan dengan proksi ROA berpengaruh signifikan terhadap kecurang (Fraud) dalam laporan keuangan sedangkan penelitian oleh (Janrosl \& Yuliadi, 2019) menunjukkan hasil bahwa kinerja keuangan dengan proksi ROA tidak berpengaruh signifikan terhadap financial statement fraud.

Dalam konteks penerapan corporate governance di bank syari'ah, para bankir syari'ah harus benar-benar merujuk kepada prinsip dan nilai ekonomi dan bisnis Islam yang telah diterapkan oleh Rasulullah yang identik dengan spirit Islamic Corporate Governance (ICG) yang dikembangkan dalam penelitian ini. Karena itu, penelitian tentang ICG sangat penting untuk dilakukan.

\section{Metode Penelitian}

Penelitian ini menguji peran kinerja keuangan atas pengaruh islamic corporate governance terhadap fraud pada Bank Syariah periode 2015-2019.

\section{A. Penelitian dan Data}

Jenis penelitian yang digunakan dalam penelitian ini adalah penelitian kuantitatif dengan menggunakan data sekunder yaitu annual report dan laporan pelaksanaan GCG dari tiap-tiap perusahaan, dan penelitian ini memiliki variabelvariabel untuk diuji, alat ukur, serta hipotesis penelitian. Penelitian kuantitatif ialah penelitian yang menekankan pada pengujian teori-teori melalui pengukuran variabel-variabel penelitian dalam suatu skala angka (numeric) dan melakukan analisis data dengan prosedur statistik. Data sekunder merupakan sumber data yang diperoleh secara tidak langsung dan menggunakan media perantara.

\section{B. Teknik Pengumpulan Data}

Sesuai dengan jenis data yang diperlukan yaitu data sekunder, maka metode pengumpulan data dalam penelitian ini adalah dengan menggunakan metode dokumentasi yaitu mendokumenter laporan keuangan dan laporan GCG pada Bank Umum Syariah (BUS) periode 2015-2019.

\section{Populasi dan Sampel}

Populasi yang digunakan dalam penelitian ini adalah Bank Umum Syariah periode 2015-2019. (Sugiyono, 2011) mengemukakan bahwa sampel adalah 
sebagian dari jumlah dan karakteristik yang dimiliki oleh populasi tersebut. Metode pemilihan sampel dalam penelitian ini adalah purposive sampling yang artinya metode pemilihan sampel dipilih berdasarkan pertimbangan (judgement sampling). Teknik pengumpulan data melalui data sekunder yang dapat diakses di situs bank umum syariah masing-masing dan menelusuri laporan tahunan yang menjadi sampel. Sampel dalam penelitian ini diambil dengan ketentuan sebagai berikut berikut:

1. Bank Umum Syariah (BUS) yang terdaftar di Bank Indonesia.

2. BUS yang telah mengungkapkan laporan keuangan dan laporan pelaksanaan GCG secara lengkap dari tahun 2015-2019.

Dari kriteria yang ditetapkan tersebut, peneliti mendapatkan jumlah sampel sebanyak 12 Perusahaan

\section{Pengujian Hipotesis}

Pengujian hipotesis dalam penelitian ini menggunakan pendekatan Partial Least Square (PLS) dengan menggunakan software SmartPLS. Menurut Wiyono PLS adalah salah satu teknik Structural Equation Modeling (SEM) yang mampu menganalisis variabel laten, variabel indikator dan kesalahan pengukuran secara langsung. (Ghozali \& Latan, 2015) menyatakan bahwa pendekatan PLS bertujuan untuk membantu peneliti untuk dapat mendapatkan nilai variabel laten untuk tujuan prediksi dan juga digunakan untuk konfirmasi teori. Dengan pendekatan PLS diasumsikan bahwa semua ukuran variance adalah variance yang berguna untuk dijelaskan. PLS memberikan model umum yang meliputi teknik korelasi kanonikal, redundancy analisis, regresi berganda, Multivariate Analysis Of Variance (MANOVA) dan principle component analysis.

\section{E. Analisis Jalur (Path Analysis)}

(Pamungkas, Ghozali, \& Achmad, 2018) menyatakan pendapatnya bahwa analisis jalur merupakan perluasan dari regresi linear berganda. Analisis jalur adalah penggunaan analisis regresi untuk menaksir hubungan kausalitas antar variabel yang telah ditetapkan sebelumnya, sedangkan menurut Noor, analisis jalur atau disebut path analysis ialah keterkaitan hubungan/pengaruh antara variabel bebas, variabel intervening, dan variabel terikat. Penelitian mendefinisikan secara jelas bahwa suatu variabel akan menjadi penyebab bagi variabel lainnya yang bisa disajikan dalam bentuk diagram. Teknik analisis jalur menggambarkan keterkaitan antara regresi berganda dengan variabel yang hendak di ukur. 


\section{Hasil dan Pembahasan}

Tabel 1 R-SquareTest

\begin{tabular}{lll}
\hline & R Square & R Square Adjusted \\
\hline FS & 0,280 & 0,018 \\
\hline Fraud & 0,041 & 0,104 \\
\hline
\end{tabular}

Hasil output statistik pada tabel di atas menunjukkan bahwa nilai Adjusted RSquare yang digunakan untuk menjelaskan model adalah pengaruh variabel eksogen (ICG, FP) terhadap variabel endogen fraud sebesar 0,018 yang berarti pengaruh variabel eksogen terhadap variabel endogen adalah 1,8\% dan sisanya 98,2\% dipengaruhi oleh variabel lain di luar model dalam penelitian ini.

Selanjutnya, nilai Adjusted $R$-Square yang dihasilkan untuk menjelaskan model kedua adalah pengaruh variabel eksogen Financial Performance terhadap variabel endogen Fraud sebesar 0,104 yang artinya terdapat pengaruh variabel eksogen terhadap variabel endogen. $10,4 \%$ dan sisanya $89,6 \%$ dipengaruhi oleh variabel lain di luar model penelitian ini.

Tabel 2

Path Coefficients (Mean, STDEV, T-Values)

\begin{tabular}{llllll}
\hline & $\begin{array}{l}\text { Original } \\
\text { Sample }(\mathbf{O})\end{array}$ & $\begin{array}{l}\text { Sample } \\
\text { Mean }(\mathbf{M})\end{array}$ & $\begin{array}{l}\text { Standard } \\
\text { Deviation } \\
(\text { STDEV) }\end{array}$ & $\begin{array}{l}\text { T Statistics } \\
(\mid \mathbf{O} / \text { STDEV })\end{array}$ & $\begin{array}{l}\mathbf{P} \\
\text { Values }\end{array}$ \\
\hline ICG $\rightarrow$ Fraud & $-0,116$ & $-0,143$ & $-0,147$ & $-1,790$ & 0,003 \\
\hline ICG $\rightarrow$ FP & 0,345 & 0,345 & 0,095 & 3,629 & 0,000 \\
\hline FS $\rightarrow$ Fraud & $-0,026$ & $-0,017$ & $-0,092$ & $-2,282$ & 0,000 \\
\hline
\end{tabular}

Table 3

Total Indirect Effects

ICG $\rightarrow$ Fraud $\quad 0,003$

\section{A. Pengaruh Islamic Corporate Governance terhadap Fraud}

H1 menyatakan bahwa terdapat pengaruh antara ICG dan Fraud. Berdasarkan hasil analisis software PLS diketahui bahwa variabel ICG berpengaruh negatif terhadap variabel Fraud. Hal ini terlihat dari nilai koefisien 0.116 dengan nilai Tstatistik -1,790 yang lebih besar dari nilai T-statistik referensi 1,96. Atas dasar ini, hipotesis pertama (H1) diterima. Terjadinya pelanggaran batas maksimum pemberian kredit, rendahnya praktek manajemen resiko, tidak adanya transparansi terhadap informasi keuangan kepada nasabah, dan adanya dominasi para pemegang saham dalam mengatur operasional perbankan menyebabkan rapuhnya industri perbankan nasional. Oleh sebab itu dengan menerapkan tata kelola perusahaan dengan baik apalagi memiliki nilai tambah dengan berlandaskan prinsip-prinsip 
Islam, memberikan indikasi dan kesan kepada masyarakat bahwa lembaga syariah terutama bank terhindar dari praktik kecurangan, walaupun kecurangan sendiri dapat terjadi dimana saja.

\section{B. Pengaruh Islamic Corporate Governance terhadap Financial Performance}

H2 menyatakan ada pengaruh positif antara ICG terhadap Financial Performance. Berdasarkan hasil analisis software PLS pada tabel ditemukan variabel ICG pengaruh terhadap variabel Financial Performance. Hal ini terlihat dari nilai koefisien 0,345 dengan nilai T-statistik 3,629 yang lebih besar dari nilai statistik-T referensi 1,96. Atas dasar ini, hipotesis pertama $(\mathrm{H} 2)$ diterima. Penerapan islamic corporate governance akan membuat investor memberikan respon yang positif terhdap kinerja keuangan dan meningkatkan nilai pasar perusahaan. Hal ini mendukung Jaya Laksana dalam penelitiannya menyatakan bahwa corporate governance secara signifikan berpengaruh positif terhadap kinerja keuangan.

\section{Pengaruh Financial Performance terhadap Fraud}

H3 menyatakan ada pengaruh Financial Performance terhadap Fraud. Berdasarkan hasil analisis software PLS pada tabel ditemukan variabel budaya pengaruh terhadap variabel Financial Performance dan Fraud. Hal ini terlihat dari nilai koefisien 0,256 dengan nilai T-statistik 2,282 yang lebih besar dari nilai statistik-T referensi 1,96. Atas dasar ini, hipotesis pertama (H3) diterima. Profitabilitas didasarkan pada harapan bahwa manajemen mampu mempertahankan atau meningkatkan tingkat profitabilitas, jika harapan ini tidak terpenuhi oleh kinerja aktual, maka hal ini dapat memotivasi bagi manajemen untuk memalsukan laporan keuangannya guna meningkatkan profit agar dapat menarik perhatian investor dan kreditor.

\section{Pengaruh Financial Performance sebagai Mediasi Islamic Corporate Governance pada Fraud}

H4 menyatakan bahwa Financial Performance dapat mediasi pengaruh Islamic Corporate Governance pada Fraud Berdasarkan hasil analisis software PLS pada tabel ditemukan variabel Financial Performance dapat memediasi pengaruh Islamic Corporate Governance terhadap Fraud. Terlihat bahwa Islamic Corporate Governance berpengaruh terhadap Financial nilai T-statistic 3,629 yang lebih besar dari nilai T-statistic referensi sebesar 1.96. Selanjutnya variabel Financial Performance memiliki pengaruh terhadap Fraud dengan nilai T-statistic 2,282 yang lebih besar dari nilai T-statistic referensi yaitu 1.96. Selain itu, perangkat lunak PLS dan pengaruh tidak langsung hanya 0,003. Atas dasar inilah maka hipotesis $(\mathrm{H} 4)$ diterima. Praktik good corporate governance yang sesuai dengan prinsip-prinsip syariah dapat mengurangi tingkat kecurangan yang terjadi dalam suatu perusahaan dengan menurunnya fraud akan mengindikasi peningkatan pada kinerja perusahaan, mengurangi resiko yang mungkin dilakukan oleh dewan dengan keputusan yang 
menguntungkan sendiri dan umumnya good corporate governance dapat meningkatkan kepercayaan investor untuk menanamkan modalnya yang berdampak terhadap kinerjanya. Penerapan good corporate governance akan membuat investor memberikan respon yang positif terhadap kinerja perusahaan sehingga akan berdampak pada fraud.

\section{Kesimpulan}

Hasil penelitian ini adalah: Islamic Corporate Governance berpengaruh negatif terhadap Fraud; Islamic Corporate Governance berpengaruh signifikan positif terhadap Kinerja Keuangan; Kinerja Keuangan berpengaruh signifikan negatif terhadap Fraud; dan Kinerja Keuangan Memediasi pengaruh Islamic Corporate Governance terhadap Fraud. 


\section{BIBLIOGRAFI}

anugrah, Ferdian. (2018). Kebijakan Pemerintah Daerah Kabupaten Tanggamus dalam Rangka Mendukung Percepatan Pembangunan Kawasan Industri Maritim di Kabupaten Tanggamus.

Arifin, Zaenal. (2005). Hubungan Antara Corporate Governance dan Variabel Pengurang Masalah Agensi. Jurnal Siasat Bisnis, 1(10).

Endraswati, Hikmah. (2015). Konsep Awal Islamic Corporate Governance: Peluang Penelitian yang Akan Datang. Muqtasid: Jurnal Ekonomi Dan Perbankan Syariah, 6(2), 89-108.

Erasiska, Erasiska, Bali, Subardi, \& Hanifah, Tengku Abu. (2015). Analisis Kandungan Logam Timbal, Kadmium dan Merkuri Dalam Produk Krim Pemutih Wajah. Riau University.

Eugene, Brigham F., \& Houston, Joel. (2010). Dasar-Dasar Manajemen Keuangan, Jakarta: PT Gramedia Pustaka Utama Ginting, Suriani. 2012. Analisis Pengaruh Pertumbuhan Arus Kas dan Profitabilitas terhadap Return Saham pada Perusahaan LQ 45 Di Bursa Efek Indonesia. Jurnal Wira Ekonomi Mikroskil, 2(01), 39-48.

Fadhistri, Karina Amanna, \& Triyanto, Dedik Nur. (2019). Pengaruh Islamic Corporate Governance Dan Sharia Compliance Terhadap Indikasi Terjadinya Fraud Pada Bank Umum Syariah Di Indonesia (studi Empiris Pada Bank Umum Syariah Periode 2014-2017). EProceedings of Management, 6(2).

Ghozali, Imam, \& Latan, Hengky. (2015). Partial Least Squares, Konsep, Teknik dan Aplikasi Menggunakan Program Smartpls 3.0 untuk Penelitian Empiris. Semarang: Badan Penerbit UNDIP.

Handayani, Susi. (2013). Pengaruh Corporate Governnace terhadap Kinerja Keuangan Pada Perusahaan BUMN (Persero) Di Indonesia. Akrual: Jurnal Akuntansi, 4(2), 183-198.

Janrosl, Viola Syukrina E., \& Yuliadi, Y. (2019). Analisis Financial Leverage, Likuiditas Dan Profitabilitas Terhadap Financial Statement Fraud pada Perusahaan Perbankan. KRISNA: Kumpulan Riset Akuntansi, 11(1), 40-46.

Jensen, Michael C., \& Meckling, William H. (1976). Theory of The Firm: Managerial Behavior, Agency Costs and Ownership Structure. Journal of Financial Economics, 3(4), 305-360.

Najib, Haifa, \& Rini, Rini. (2016). Sharia Compliance, Islamic Corporate Governance dan Fraud pada Bank Syariah. Jurnal Akuntansi Dan Keuangan Islam, 4(2), 131146.

Ngumar, Sutjipto, Fidiana, Fidiana, \& Retnani, Endang Dwi. (2019). Implikasi Tata 
Kelola Islami pada Fraud Bank Islam. Jurnal Reviu Akuntansi dan Keuangan, 9(2), 226-239.

Novitasari, Dyah Putri, Diana, Nur, \& Mawardi, M. Cholid. (2017). Pengaruh Mekanisme Good Corporate Governance terhadap Kinerja Keuangan (Studi Pada Bank Umum Syariah yang Terdaftar DI BEI Tahun 2012-2016). Jurnal Ilmiah Riset Akuntansi, 6(04).

Nur'aini, Chassandra. (2016). Pengaruh Debt To Asset Ratio, Pertumbuhan Aset, Return On Assets, Rasio Dewan Komisaris Independen, Dan Reputasi Kap Terhadap Financial Statement Fraud Pada Perusahaan Sektor Industri Barang Konsumsi Di Bursa Efek Indonesia (BEI) Periode 2011-2014. Jurnal Skripsi Fakultas Ekonomi Universitas Maritim Raja Ali Haji, 1.

Pamungkas, Imang Dapit, Ghozali, Imam, \& Achmad, Tarmizi. (2018). A Pilot Study of Corporate Governance and Accounting Fraud: The Fraud Diamond Model. Journal of Business and Retail Management Research, 12(2).

Rahmayani, Rahmayani, \& Rahmawaty, Rahmawaty. (2017). Pengaruh Islamic Corporate Governance dan Internal Control terhadap Indikasi Terjadinya Fraud Pada Bank Umum Syariah Di Indonesia. Syiah Kuala University.

Rajagukguk, Thetty S. (2017). Pengaruh Internal Audit dan Pencegahan Fraud terhadap Kinerja Keuangan (Studi Kasus pada PT Perkebunan Nusantara IV). Owner: Riset Dan Jurnal Akuntansi, 1(1).

Rini, Rini. (2014). The Effect of Audit Committee Role and Sharia Supervisory Board Role on Financial Reporting Quality at Islamic Banks in Indonesia. Journal of Economics, Business, \& Accountancy Ventura, 17(1), 145-156.

Safieddine, Assem. (2009). Islamic Financial Institutions and Corporate Governance: New Insights for Agency Theory. Corporate Governance: An International Review, 17(2), 142-158.

Sugiyono, Prof. (2011). Metodologi Penelitian Kuantitatif Kualitatif dan $R \& D$. Alpabeta: Bandung. 